\title{
DETERMINATION OF MAJOR ANTINUTRITIONAL FACTORS IN PENNISETUM GLAUCUM L. AND THEIR RELATIONSHIP WITH PROTEIN AND CONTENT YIELD
}

\author{
Bunty Sharma*, Laxman Kumar Chugh ${ }^{1}$, Vivek K Singh ${ }^{2}$, Vikram Singh ${ }^{2}$ \\ and Meenakshi Sood
}

Chitkara School of Health Sciences, Chitkara University, Punjab, India

Keywords: Pearl millet, Antinutritional factors, C-glycosylflavones, Phytic acid

\begin{abstract}
Twenty pearl millet genotypes were used to explore and evaluate the diversity of antinutritional factors along with establishing their relationship with protein content and yield that contributes to its quality and farmers interest, respectively. A wide variation was observed for each of antrinutritional factors along with protein $(7.54-11.94 \%)$ and yield $(19.67-27.6 \mathrm{~g} / \mathrm{plant})$. The genotype HBL-0825-1 identified for having highest phenol, phytic acid and C-glycosylflavone content while genotype 78/711 for lowest Cglycosylflavone and phytic acid content along with maximum protein content. HBL-72 was identified for having maximum yield. Significant positive correlation was observed within most of the antinutritional factors, whereas protein possessed negative and significant correlation with phytic acid content. On the other hand, phytic acid exerted a positive and direct effect while C-glycosylflavones had negative effect on grain yield per plant, which could be utilized for further breeding improvement programmes that can contribute to popularity towards increased use of pearl millet.
\end{abstract}

Pearl millet (Pennisetum glaucum) is a rich source of vitamin, energy and minerals which are potentially useful for human health and several potential health benefits such as preventing cancer and cardiovascular diseases, reducing tumour incidence (Gupta et al. 2012, Singh et al. 2014). It has important contribution to national food security due to its good sustainability in adverse agroclimatic conditions (Jukanti et al. 2017). In spite of its superior agro-climatic and nutritional qualities, its usage is quite limited due to its unappealing grey color and presence of antinutritional factors viz, phytic acid, polyphenols and C-glycosylflavones, which ultimately affects the bioaccessibility and bioavailability of the dietary mineral such as calcium, zinc and iron and vitamin E in gastrointestinal tract in humans (Sokrab et al. 2012). Among these antinutritional components, phytic acid is of prime obstacle in human nutrition and health management directly due to its chelating activity while polyphenols are mainly responsible for its grey colour and reduces the nutritive values, while C-glycosylflavone and their metabolites in pearl millet are well known for their goitrogenic properties.

To improve the nutritional quality and reduce the anti-nutritional factors of pearl millet, the knowledge about the anti-nutirtional factors and their relation with protein and yield to minimise the nutrient loss is required. Therefore keeping this in consideration, an experiment with different pearl millet genotypes was conducted (1) To identify the diversity of anti-nutritional factors and the relationship existing within these factors (2) to study effects of anti-nutritional factors on protein and yield, which would be useful in designing breeding improvement programmes.

Twenty diverse pearl millet genotypes (78/711, HBL 0706, HBL0902, HBL0551, HBL0566, HBL08251, HBL0828-1, HBL0828-2, HBL0829-1, HBL0832, HBL0843-2, HBL72, HC20-S2, HMS18B, HMS55B, HMS60B, ICMB03888, ICMB52222, ICMB93333 and LPBL10/120) were

\footnotetext{
*Author for correspondence: <bunty.sharma@chitkara.edu.in>. ${ }^{1}$ Department of Biochemistry, Chaudhary Charan Singh Haryana Agricultural University, Hisar, India. ${ }^{2}$ Department of Genetics and Plant Breeding, Chaudhary Charan Singh Haryana Agricultural University, Hisar, India.
} 
sown with randomized block design in a single row of 3 meter length with inter and intra row spacing of $30 \mathrm{~cm}$ and $15 \mathrm{~cm}$, respectively during Kharif 2014 at the research farm of Department of Genetics and Plant Breeding, CCS H.A.U., Hisar. The grains were collected from individual plants, cleared and stored at ambient temperature for further use.

The Micro-Kjeldahl's method of Humphries (1956) was used for the estimation of nitrogen content, which was multiplied by 6.25 to obtain crude protein content and expressed in g per $100 \mathrm{~g}$ of grain.

Phytic acid was estimated using the method of Haug and Lentzsch (1983). Total phenols were estimated by following the method of Malik and Singh (1980). A standard curve drawn using different concentrations of catechol $(0-100 \mathrm{mg} / \mathrm{ml})$ was used to calculate total phenol content and expressed as $\mathrm{mg}$ total phenols/100 $\mathrm{g}$ dry flour.

C-glycosylflavone was estimated by using the method of Akingbala (1991). Concentration was reported in terms of $\mathrm{mg} / 100 \mathrm{~g}$ glucosylvitexin equivalents on dry weight basis. The data were analyzed by using the Indostat software version 8.1. DMRT was applied to know the differences among the genotypes $(\mathrm{F}<0.05)$.

The analysis of variance revealed the highly significant difference at $\mathrm{p}<0.01$ for all the five traits among 20 genotypes used for the study (Table 1). The mean performance of 20 genotypes for total phenols, C-glycosylflavone, phytic acid, protein content and grain yield is presented in Table 2. Significant differences existed among the genotypes for five biochemical characteristics.

Table 1. Analysis of variance for five biochemical characteristics among 20 selected pearl millet genotypes.

\begin{tabular}{lcccccc}
\hline $\begin{array}{l}\text { Source of } \\
\text { variation }\end{array}$ & df & $\begin{array}{c}\text { Total phenols } \\
(\mathrm{mg} / 100 \mathrm{~g})\end{array}$ & $\begin{array}{c}\text { C-glycosylflavone } \\
(\mathrm{mg} / 100 \mathrm{~g})\end{array}$ & $\begin{array}{c}\text { Phytic acid } \\
(\mathrm{mg} / 100 \mathrm{~g})\end{array}$ & $\begin{array}{c}\text { Protein } \\
(\%)\end{array}$ & $\begin{array}{c}\text { Grain yield } \\
(\mathrm{g})\end{array}$ \\
\hline Genotypes & 19 & $5212.71 * *$ & $709.63^{* *}$ & $48696.37 * *$ & $5.44 * *$ & $80.43^{* *}$ \\
Error & 40 & 21.77 & 15.15 & 31.70 & 0.12 & 0.96 \\
Total & 59 & 1693.43 & 238.80 & 15703.37 & 1.84 & 26.55 \\
\hline
\end{tabular}

$*$ and $* *$ significance at 5 and $1 \%$ level.

The range of protein content was from 7.54 (HBL 0825-1) to 11.94 (78/711) per cent. Eleven genotypes possessed significantly higher protein content than the general mean of $9.89 \%$. A large variation in protein content (6-21\%) was reported by Hassan et al. (2014) in pearl millet.

The genotype HBL 0825-1 possessed the highest phenol content $(291 \mathrm{mg} / 100 \mathrm{~g})$ followed by HBL 828-2 (289 mg/100 g). Seven genotypes had significantly higher phenol content than the general mean of $213 \mathrm{mg} / 100 \mathrm{~g}$. The total phenol content as high as $441.26 \mathrm{mg} / 100 \mathrm{~g}$ (Nour et al.2014) and as low as $50.87 \mathrm{mg} / 100 \mathrm{~g}$ (Yadav et al. 2010) has been reported in pearl millet. Apart from contributing to grey colour, phenols also act as antinutritional factor by interrupting the utilization of protein and starch as it forms stable complexes with protein and inhibit the activity of trypsin and amylase specially (Pawar and Parlikar 1990), hence, low total phenols are desirable in pearl millet.

The C-glycosylflavone, which is mainly found in outer layers of grain (Reicert 1979), is a unique phenolic compound of pearl millet and has significant contribution in grey colour of pearl millet grains along with causing undesirable mousy odour in grounded flour (Taylor 2004). It ranged from 85 (78/711) to 148 (HBL $0825-1) \mathrm{mg} / 100 \mathrm{~g}$. Eleven entries had significantly higher C-glycosylflavone content than the general mean of $116 \mathrm{mg} / 100 \mathrm{~g}$. 
Being strong chelating agent the phytic acid reduces the bioavailability of minerals, proteins, amino acids and other essential dietary nutrients and objectionable for human consumption (Singh et al. 2014). Twelve genotypes were observed for having high phytic acid content than the general mean of $632 \mathrm{mg} / 100 \mathrm{~g}$. The lowest and highest value for phytic acid was observed in genotype 78/711 (349 mg/100 g) and HBL 0825-1 (783 mg/100 g), respectively. Table 3 showed significantly positive correlation of phytic acid with C-glycosylflavone content $\left(0.320^{* *}\right)$. The phytic acid was as high as 825.7 and as low as $1.67 \%$ in pearl millet flour (Kumar and Chauhan 1993). Variations in phytic acid might be attributed to both genetic and environmental conditions.

Table 2. Performance of $\mathbf{2 0}$ selected pearl millet genotypes for total phenols, C-glycosylflavone, phytic acid, protein and grain yield.

\begin{tabular}{|c|c|c|c|c|c|c|}
\hline $\begin{array}{l}\text { Sl. } \\
\text { No. }\end{array}$ & Genotypes & $\begin{array}{l}\text { Total phenols } \\
(\mathrm{mg} / 100 \mathrm{~g})\end{array}$ & $\begin{array}{l}\text { C-glycosylflavone } \\
(\mathrm{mg} / 100 \mathrm{~g})\end{array}$ & $\begin{array}{l}\text { Phytic acid } \\
(\mathrm{mg} / 100 \mathrm{~g})\end{array}$ & $\begin{array}{l}\text { Protein } \\
(\%)\end{array}$ & $\begin{array}{l}\text { Grain } \\
\text { yield }(\mathrm{g})\end{array}$ \\
\hline 1 & $78 / 711$ & $169^{\mathrm{i}}$ & $85^{\mathrm{i}}$ & $349^{q}$ & $11.92^{\mathrm{a}}$ & $20.23^{\text {efg }}$ \\
\hline 2 & HBL 0706 & $181^{\mathrm{h}}$ & $118^{\text {ef }}$ & $703^{g}$ & $9.55^{\mathrm{de}}$ & $22.4^{\mathrm{e}}$ \\
\hline 3 & HBL 0902 & $267^{\mathrm{b}}$ & $125^{\text {cde }}$ & $669^{h}$ & $9.98^{\mathrm{cd}}$ & $18.07^{\mathrm{hi}}$ \\
\hline 4 & HBL 0551 & $206^{\text {efg }}$ & $112^{\mathrm{fg}}$ & $500^{n}$ & $11.65^{\mathrm{a}}$ & $25.1^{\mathrm{d}}$ \\
\hline 5 & HBL 0566 & $205^{\mathrm{efg}}$ & $93^{\mathrm{i}}$ & $564^{1}$ & $10.85^{b}$ & $26.81^{b c}$ \\
\hline 6 & HBL 0825-1 & $291^{\mathrm{a}}$ & $148^{\mathrm{a}}$ & $783^{a}$ & $7.54^{\mathrm{h}}$ & $19.67^{\text {fgh }}$ \\
\hline 7 & HBL 0828-1 & $183^{h}$ & $104^{\mathrm{h}}$ & $589^{\mathrm{k}}$ & $10.76^{\mathrm{bcd}}$ & $20.3^{\mathrm{efg}}$ \\
\hline 8 & HBL 0828-2 & $289^{a}$ & $117^{\text {ef }}$ & $532^{\mathrm{m}}$ & $10.94^{\mathrm{ab}}$ & $27.07^{\mathrm{b}}$ \\
\hline 9 & HBL 0829-1 & $195^{\mathrm{g}}$ & $130^{\mathrm{bc}}$ & $649^{\mathrm{i}}$ & $10.11^{\mathrm{bcd}}$ & $26.13^{b c}$ \\
\hline 10 & HBL 0832 & $181^{\mathrm{h}}$ & $127^{\mathrm{bcd}}$ & $764^{b c}$ & $7.79^{h}$ & $15.68^{\mathrm{jk}}$ \\
\hline 11 & HBL 0843-2 & $236^{\mathrm{d}}$ & $120^{\mathrm{de}}$ & $697^{\mathrm{g}}$ & $9.62^{\mathrm{de}}$ & $19.43^{\text {ghi }}$ \\
\hline 12 & HBL 72 & $226^{d}$ & $126^{\text {cde }}$ & $755^{\mathrm{cd}}$ & $8.29^{\mathrm{f}}$ & $29.6^{\mathrm{a}}$ \\
\hline 13 & $\mathrm{HC} 20-\mathrm{S} 2$ & $210^{\mathrm{ef}}$ & $115^{\mathrm{f}}$ & $749^{d}$ & $8.32^{\mathrm{fg}}$ & $27.7^{\mathrm{ab}}$ \\
\hline 14 & HMS 18B & $209^{\text {ef }}$ & $101^{\mathrm{h}}$ & $720^{f}$ & $9.37^{\mathrm{de}}$ & $26.93^{b}$ \\
\hline 15 & HMS 55B & $265^{b}$ & $105^{\mathrm{gh}}$ & $734^{e}$ & $9.2^{\mathrm{e}}$ & $25.63^{\mathrm{cd}}$ \\
\hline 16 & HMS-60B & $163^{\mathrm{j}}$ & $113^{f}$ & $412^{p}$ & $11.76^{\mathrm{a}}$ & $21.03^{\text {ef }}$ \\
\hline 17 & ICMB 03888 & $186^{\mathrm{h}}$ & $121^{\text {de }}$ & $634^{\mathrm{i}}$ & $10.27^{\mathrm{bcd}}$ & $12.27^{1}$ \\
\hline 18 & ICMB 52222 & $243^{c}$ & $130^{\mathrm{bc}}$ & $611^{\mathrm{j}}$ & $10.45^{\mathrm{bc}}$ & $28.43^{\mathrm{ab}}$ \\
\hline 19 & ICMB 93333 & $211^{\mathrm{e}}$ & $134^{\mathrm{b}}$ & $456^{\circ}$ & $11.69^{\mathrm{a}}$ & $15.53^{\mathrm{k}}$ \\
\hline 20 & LPBL 10/120 & $144^{\mathrm{k}}$ & $99^{\mathrm{h}}$ & $771^{\mathrm{ab}}$ & $7.64^{\mathrm{gh}}$ & $18.06^{\mathrm{ij}}$ \\
\hline \multicolumn{2}{|c|}{ General mean } & 213 & 116 & 632 & 9.89 & 22.31 \\
\hline
\end{tabular}

Means, in each column, following similar letter(s) are not significantly different at the $5 \%$ level of probability using DMRT.

The genotype 78/711 was observed for having highest protein content (11.94) but lowest phytic acid $(349 \mathrm{mg} / 100 \mathrm{~g})$ and lowest C-glycosyflavone content. Similarly, the genotype HBL $0825-1$ had the lowest protein content $(7.54 \%)$ and highest phytic acid $(783 \mathrm{mg} / 100 \mathrm{~g})$. A significantly high and negative correlation $(-0.817 * *)$ was observed between protein and phytic acid (Table 3), meaning that there was a decrease in phytic acid with the increase in protein content, which signifies an important and desirable trait for selecting the lines having low phytic acid that is undesirable with correspondingly increase in the protein, which is a desired character. Similar correlation was reported by Sokrab et al. (2012). The genotype HBL 72 gave the highest grain yield of $29.60 \mathrm{~g} /$ plant followed by HC20-32 $(27.70 \mathrm{~g})$. The lowest value was noted in ICMB $03888(12.27 \mathrm{~g})$. Ten entries had significantly higher grain yield than the general mean of $22.31 \mathrm{~g}$. 
The grain yield of HBL 825-1, which had lowest protein and high phenol content and phytic acid, was $19.67 \mathrm{~g}$. The grain yield of the genotype (78/711) with highest protein content and lowest Cglycosylflavone content was $20.23 \mathrm{~g}$.

For grain yield, phytic acid and total phenol, the GCV was high, and for $C$-glycosylflavone and protein content, it was moderate (Table 4). These high GCV estimates obtained for grain yield, phtyic acid and total phenols indicated quite large extent of genetic variation for these characters. High heritability associated with high genetic advance as the percentage of mean observed for these characters indicates that these are mostly governed by additive gene action and the selection could be beneficial. All genotypes had high heritability and genetic advance as per cent of mean for all five traits. The grain yield and C-glycosylflavone content had positive and significant $(\mathrm{p}<0.01)$ correlation with total phenol content having value of $0.300^{*}$ and $0.477 * *$, respectively (Table 3 ). The protein content had a negative and significant genotypic correlation with phytic acid $\left(-0.817^{* *}\right)$.

Table 3.Phenotypic correlation coefficient among five characters in pearl millet.

\begin{tabular}{lccccc}
\hline Characters & Total phenols & C-glycosylflavones & Phytic acid & Protein & Grain yield (g) \\
\hline Total phenols & 1 & & & & \\
C-glycosylflavones & $0.477^{* *}$ & 1 & & & \\
Phytic acid & 0.240 & $0.320^{* *}$ & 1 & & \\
Protein & -0.063 & -0.214 & $-0.817^{* *}$ & 1 & \\
Grain yield/plant (g) & $0.300^{*}$ & -0.144 & 0.103 & 0.0370 & 1 \\
\hline
\end{tabular}

Table 4. Coefficient of variability, heritability and genetic advance of biochemical characteristics of Pearl millet grains.

\begin{tabular}{llllllc}
\hline \multirow{2}{*}{ Characters } & Mean & Range & \multicolumn{2}{c}{$\begin{array}{c}\text { Coefficient of } \\
\text { variability }\end{array}$} & $\begin{array}{c}\text { Heritability } \\
(\%)\end{array}$ & $\begin{array}{c}\text { GA as per cent } \\
\text { of mean }\end{array}$ \\
\cline { 4 - 5 } & & & PCV & GCV & & \\
\hline Total phenols & 213 & $144-291$ & 19.76 & 19.63 & 98.75 & 40.19 \\
C-glycosylflavone & 116.15 & $99-148$ & 13.43 & 13.00 & 93.78 & 25.94 \\
Phytic acid & 632.05 & $771-783$ & 20.20 & 20.19 & 99.83 & 41.54 \\
Protein & 9.89 & $7.54-11.92$ & 14.12 & 13.27 & 88.29 & 25.69 \\
Grain yield & 22.31 & $12-29$ & 24.05 & 22.42 & 86.91 & 43.06 \\
\hline
\end{tabular}

In general, simple correlation does not give a clear picture of association between different traits of a crop species, thus, one should go for path coefficient analysis, which is based on cause effect relationship. It is noted from Table 5 that the highest positive and direct effect on grain yield per plant was exerted by phytic acid (0.677) followed by protein $(0.585)$ and total phenols $(0.433)$. The highest negative and direct effect was also observed for the character C-glycosylflavones $(-0.474)$, which means that a slight increase in any one of the above traits might directly contribute towards grain yield per plant. Highly positive and indirect effect on grain yield per plant was exerted by phytic acid (0.226), total phenols (0.212) and C-glycosylflavones (0.119) via phytic acid. This suggests that phytic acid, total phenols and C-glycosylflavone were the most important indirect contributors to grain yield per plant via phytic acid. The remaining estimates of indirect effects in the analysis were too low to be considered important. The acquisition of new 
germplasm and its evaluation are essential to select new desirable genotypes and to use them in the breeding programme for the development of high yielding varieties.

Table 5. Direct (bold) and indirect effects of biochemical characters on grain yield.

\begin{tabular}{lccccc}
\hline Characters & $\begin{array}{c}\text { Total } \\
\text { phenols }\end{array}$ & C-glycosylflavone & $\begin{array}{c}\text { Phytic } \\
\text { acid }\end{array}$ & Protein & $\begin{array}{c}\text { Genotypic coefficient } \\
\text { of variation }\end{array}$ \\
\hline Total phenols & $\mathbf{0 . 4 3 3}$ & -0.233 & 0.164 & -0.042 & 19.398 \\
C-glycosylflavone & 0.212 & $-\mathbf{0 . 4 7 4}$ & 0.226 & -0.147 & 12.884 \\
Phytic acid & 0.105 & -0.158 & $\mathbf{0 . 6 7 7}$ & -0.512 & 20.285 \\
Protein & -0.031 & 0.119 & -0.594 & $\mathbf{0 . 5 8 5}$ & 14.496 \\
\hline
\end{tabular}

Genetic variability, heritability, correlations among yield and yield attributing/quality traits coupled with their mutual direct and indirect effects form the basis of selection and deciding breeding schemes in crop improvement programmes. In the present experiment antinutritional factors recorded high heritability and genetic variation which were positively correlated with the yield. However, it is not desirable because their simultaneously improvement through simple selection schemes is not possible. Therefore, special breeding schemes need to be designed for improving yield and protein content with simultaneously decrease in antinutritional factors. Genotype 78/711 was identified for higher protein content and low phytic acid and Cglycosylflavone; HBL72 for higher yield and LPBL 10/120 for low phenol content. Crossing schemes involving these three parents have been illustrated to achieve target genotype having higher protein content, high yield and low antinuritional factors.

\section{References}

Akingbala JO, Oguntimehin B, Abass AB 1991. Effects of processing methods on the quality and acceptability of fufu from low cyanide cassava. J. Sci. Food Agric. 57(1): 151-154.

Gupta N, Srivastava AK and Pandey VN 2012.Biodiversity and nutraceutical quality of some Indian millet. PNAS, 2, 265-273.

Hassan MU, Ahmad A, Zamir SI, Haq I, Khalid F, Rasool T and Hussain A 2014. Growth, yield and quality performance of pearl millet (Pennisetum americanum L.) Varieties under Faisalabad conditions, Pakistan. AJPS, 9 (9):2215-2223

Haug W and Lentzsch HJ 1983. Sensitive method for the rapid determination of phytic acid in cereals and cereal products. J. Sci. Food and Agri. 34: 1423-1426.

Humphries ES 1956. Mineral components and ash analysis. Modern Methods of Plant Analysis/Moderne Methoden der Pflanzenanalyse, In: Springer-Verlag OHG, Berlin Gottingen Heidelberg. pp. 468-502.

Jukanti AK, Manga VK, Bhatt RK and Pathak R 2017. Differential response of pearl millet genotypes to high temperature stress at flowering. J. Envir. Bio. 38: 791-791.

Kumar A and Chauhan BM 1993. Effects of phytic acid on protein digestibility (in vitro) and HCLextractability of minerals in pearl millet sprouts. Cereal Chem. 70: 504-506.

Malik CP and Singh MB 1980. Extraction and estimation of amino acids and ketoacids. In: C.P. Malik \& M.B. Singh (eds.): Plant Enzymology and Histo-Enzymology, Kalyani Publishers, New Delhi and Indhiana, India. pp. 286-287.

Nour AAM, Sokrab AM, Ahmed IAM and Babiker EE 2014. Supplementation and cooking of pearl millet: changes in anti-nutrients, and total minerals content and extractability. Inno. Roma. Food Biotech. 15: 922 .

Pawar VD and Parlikar GS 1990. Reducing the polyphenols and phytic acid and improving the protein quality of pearl millet by dehulling and soaking. JFST. 27: 140-143.

Reichert RD 1979 The pH sensitive pigments in pearl millet. Cereal Chem. 56: 291-294 
Singh SD, Sihag S, Sihag ZS and Chugh LK 2014. Effect of replacing maize with pearl millet on egg production and quality in layers. Ind. J. Animal Nutri. 31: 92-96.

Sokrab AM, Mohamed Ahmed IA and Babiker EE 2012. Effect of fermentation on antinutrients, and total and extractable minerals of high and low phytic acid corn genotypes. J. Saudi Soc. Agri Sci. 11: 123128.

Taylor JRN 2004. Pearl millet: Encyclopaedia of Grain Science; In: C. Wrigley, H. Corke and C.E. Walker (eds.): Elsevier Amsterdam, 53-261.

Yadav DK, Chhabra AK, Yadav HP and Chugh LK 2010. Studies on biochemical traits for rancidity in pearl millet (Pennisetum glacucum L. R.Br.). Forage Res. 36: 37-41.

(Manuscript received on 9 June, 2018; revised on 8 July, 2019) 